\title{
Pengaruh Akuntabilitas dan Transparansi Terhadap Minat Muzakki Membayar Zakat di BAZNAS Sragen
}

\author{
Nur Kabib $^{1 *)}$, Ahmad Ulil Albab Al Umar ${ }^{2)}$, Ana Fitriani ${ }^{3)}$, Lora Lorenza ${ }^{4)}$, Muammar Taufiqi Lutfi \\ Mustofa ${ }^{5}$ \\ 1,2,3,4,5 Fakultas Ekonomi dan Bisnis Islam, IAIN Salatiga \\ *Email korespondensi : nurkabib@iainsalatiga.ac.id
}

\begin{abstract}
This study aims to analyze the effect of accountability and transparency on muzakki's interest in paying zakat. The population in this study are people who pay zakat in BAZNAS, Sragen Regency. The sample in this study produced 100 respondents. The sample selection technique used purposive sampling and then used the Slovin formula. The data analysis method in this study uses multiple linear regression. The results of this study indicate that partially the accountability variable that affects the interest in paying zakat, then partially the transparency variable does not have a significant effect on the interest of muzakki to pay zakat. Simultaneously, the variables of accountability and transparency have an effect on the interest in paying zakat.
\end{abstract}

Keywords : Accountability, Intens, Transparancy, Zakah

Saran sitasi: Kabib, N., Umar, A. U., Fitriani, A., Lorenza, L., Lutfi, M. T., \& Mustofa. (2021). Pengaruh Akuntabilitas dan Transparansi Terhadap Minat Muzakki Membayar Zakat di BAZNAS Sragen. Jurnal Ilmiah Ekonomi Islam, 7(01), 341-349. doi: http://dx.doi.org/10.29040/jiei.v7i1.2156

DOI: http://dx.doi.org/10.29040/jiei.v7i1.2156

\section{PENDAHULUAN}

Indonesia merupakan negara dengan jumlah penduduk keempat terbesar di Dunia sekaligus menjadi negara muslim terbesar di Dunia. Dimana 87,18\% masyarakatnya adalah muslim (BPS, 2020). Potensi muslim yang besar ini seharusnya berbanding besar pula dengan potensi zakat. Namun pada kenyataannya realisasi zakat di Indonesia masih rendah (Istiqomah \& Asrori, 2019). Salah satu dari rukun islam adalah zakat sehingga hukumnya adalah wajib. Atas dasar hal tersebut, setiap muslim yang mampu diwajibkan untuk membayar zakat sesuai ketetapan yang berlaku dalam syariah Islam. Zakat merupakan salah satu ibadah pokok dalam Islam yang dapat menjadi tool dan menjadi pilar guna menegakkan keadilan dalam kehidupan sosial dan bisa meningkatkan kesejahteraan umat (Rahman, 2015). Pengelolaan zakat yang baik berguna untuk memajukan kesejahteraan yang dapat dirasakan oleh seluruh masyarakat. Zakat yang dikelola dengan maksimal juga mendorong program pembangunan berkelanjutan atau Sustainable Development Goals (Amymie, 2019).

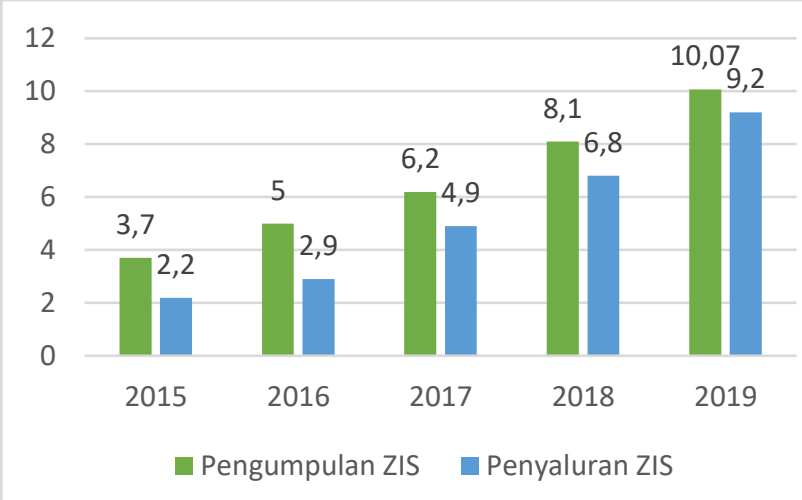

Sumber : Data diolah, 2020

Grafik 1. Pengumpulan dan penyaluran ZIS (dalam triliun)

Berdasarkan data grafik 1 meskipun terdapat kenaikan di setiap tahunnya meliputi pengumpulan dan penyaluran dana ZIS oleh BAZNAS dan LAZ. Namun demikian angka tersebut masih jauh dengan potensi zakat di Indonesia pada tahun 2020 yang ditarget mencapai 230 triliun, namun nyatanya dana yang terkumpul baru 8 triliun atau setara 3,5\% dari potensi (Lokadata.com, 2020). Hal ini yang menjadikan masalah dalam pengumpulan atau kesadaran masyarakat Indonesia pada masa sekarang. 
Kesenjangan antara dana yang terkumpul dengan dana yang disalurkan tersebut menandakan bahwa adanya masalah dalam marketing dan peruntukannya terkait dengan kepercayaan masyarakat terhadap Lembaga pengelola zakat selama ini (Nurhasanah \& Suryani, 2018). Hal ini juga didukung oleh Lubis (2014) yang menyatakan bahwa salah satu faktor keengganan masyarakat membayar zakat pada Badan Amil Zakat adalah kurangnya kepercayaan masyarakat terhadap BAZIS/LAZ.

Menurut survei oleh PIRAC (2007) pada tahun 2007 menemukan bahwa 55\% masyarakat muslim sadar dan mengakui diri sebagai muzakki. Jumlah ini meningkat dibandingkan pada tahun 2004 yang berkisar $49,8 \%$ artinya terjadi peningkatan sebesr $5,2 \%$. Peningkatan tingkat kesadaran ini telihat dari kepatuhan muzakki untuk menunaikan zakat. Dari sebagian responden yaitu 95,5\% mengaku bahwa dirinya adalah muzakki dan menunaikan kewajiban berzakat. Namun menurut PIRAC (2007) menemukan bahwa masyarakat memiliki kepercayaan yang rendah terhadap Lembaga Pengelola Zakat. Hal ini dibuktikan masyarakat yang sudah menyalurkan zakatnya pada BAZ dan LAZ masing-masing hanya sebesar $6 \%$ dan $1,2 \%$. Masyakarat $(59 \%)$ cenderung memilih menyalurkan zakatnya kepada masjid di sekitar rumah dan zakat melalui Lembaga menurun.

Berdasarkan implementasi zakat di masyarakat muslim Indonesia tampaknya masih ada celah antara harapan dan kenyataan; mayoritas orang Indonesia beragama Islam - dengan potensi dana zakat yang besar - namun kenyataannya dana zakat terkumpul secara nasional melalui lembaga zakat jauh dari apa yang diharapkan. Di Indonesia, agen penagihan dan penyaluran dana zakat (yang telah diatur dalam peraturan perundang-undangan) telah dibuat tetapi tidak ada perangkat hukum yang dapat memaksa umat Islam untuk membayar zakat. Berdasarkan hal tersebut, kesadaran dalam membayar zakat akan dipengaruhi oleh pemahaman masyarakat tentang zakat (Widiyanto, 2017). Dalam implementasinya muzakki merasa sudah mengeluarkan zakat kepada mustahik sesunggguhnya, namun kenyataannya hanya didasarkan karena kedekatan emosi belaka. Misal di distribusikan kepada sanak saudaranya sendiri, yang menurut dirinya kerabatnya itu dalam kategori mustahik, padahal jika diperhatikan dengan seksama masih banyak orang-orang yang lebih berhak untuk menerimanya seperti lebih miskin, lebih fakir dan lebih menderita dibandingkan dengan kerabatnya tersebut (Basri, 2015). Hingga masa sekarang masyarakat memilih dan menggunakan model penyaluran zakat secara door to door maupun tradisional dengan memilih masjid, dengan dalih bahwa hal tersebut dekat rumah yang lebih didasari kepraktisan dan kedekatan lokasi (Harahap, 2019).

Pernyataan Standar Akuntansi Keuangan (PSAK) No. 109 yang dibuat oleh Ikatan Akuntan Indonesia (IAI) menjelaskan bahwa organisasi pengelola zakat diinginkan dapat menyajikan laporan keuangan sesuai dengan peraturan tersebut. Penerapan standar PSAK 109 dimulai pasca 2008, yang sebelumnya masih merujuk pada PSAK 45 mengenai pelaporan keuangan organisasi nirlaba. Zakat merupakan salah satu bentuk transaksi syariah dalam domain sosial jadi perlu peraturan sendiri terhadap perlakuan akuntansi nya yang bersifat standar sebagaimana dalam transaksi komersial lainnya seperti mudharabah, musyarakah, murahabah, salam, ijarah, istishna, dan lainnya. Oleh karena itu, diperlukan Lembaga-lembaga zakat yang dikelola dengan manajemen yang baik.

Tantangan kedepan mengenai pengelolaan zakat adalah bagaimana meningkatkan koordinasi antara lembaga zakat di Indonesia. Sehingga dana zakat dapat dikelola dengan baik. Organisasi Pengelola Zakat akan mencapai optimalisasi penghimpunan zakat dengan baik apabila Organisasi Pengelola Zakat dapat menepis keraguan para muzakki mengenai profesionalitas Organisasi Pengelola Zakat dalam menerapkan prinsip akuntabilitas dan transparansi.

Uraian diatas dapat dilihat bahwa rasa ragu-ragu terhadap Organisasi Pengelola Zakat menyebabkan muzakki cenderung memilih untuk menghitung dan mendistribusikan zakatnya sendiri kepada mustahik. Adapun faktor-faktor yang diketahui mampu menyebabkan rasa kurang percaya muzakki kepada Organisasi Pengelola Zakat adalah akuntabilitas dan transparansi yang dilakukan oleh pengelolaaan zakat. Hal ini diungkapkan oleh Hasrina, Yusri, \& Sy (2019) yang mengatakan bahwa akuntabilitas dan transparasi dapat memengaruhi signfikan terhadap kepercayaan muzakki. Penelitian oleh Amalia \& Widiastuti (2019) dan Yuliafitri \& Khoiriyah (2016) menemukan bahwa akuntabilitas memengaruhi secara positif dan signifikan terhadap minat muzakki membayar zakat. Sedangkan Penelitian oleh Amelia \& Murtani (2020) mengemukakan hal yang berbeda bahwa akuntabilitas memengaruhi positif namun tidak signifikan terhadap minat muzakki membayar zakat. 
Faktor akuntabilitas dan transparansi merupakan wujud tanggung jawab Lembaga Pengelola Zakat dalam memenuhi kewajiban kepada masyarakat. Hal tersebut akan menimbulkan rasa percaya dari masyarakat. Kepercayaan diartikan sebagai rasa percaya terhadap sesuatu. Dari pengertian ini, kepercayaan merupakan faktor seseorang terhadap Lembaga Pengelola Zakat. Apabila kepercayaan seseorang sudah terbentuk maka akan menimbulkan minat seseorang membayar zakat. Hasil Penelitian oleh Amalia \& Widiastuti (2019) mengemukakan bahwa akuntabilitas dan transparansi secara simultan dapat memengaruhi minat muzakki untuk membayar zakat. Namun berbeda halnya dengan Ilyas Junjunan, Asegaf, \& Takwil (2020) menemukan bahwa akuntabilitas dan transparansi tidak berpengaruh pada kepercayaan muzakki.

Menurut Muthohar (2016) mengemukakan mengenai opini kepercayaan masyarakat terhadap Lembaga zakat pemerintah masih rendah dibandingkan dengan lembaga zakat swasta. Hal tersebut berarti kepercayaan masyarakat dalam membayar zakat sangat kurang terutama pada Lembaga zakat pemerintah. Apabila seseorang sudah percaya terhadap sebuah Lembaga zakat maka otomatis menimbulkan minat muzakki untuk membayar zakat.

Alasan peneliti memilih melakukan penelitian pada BAZNAS di Sragen adalah karena ingin mengetahui apakah terdapat pengaruh akuntabilitas dan transparansi terhadap kepercayaan dan minat muzaki membayar zakat pada BAZNAS di Sragen. Kemudian alasan lain peneliti memilih BAZNAS Kabupaten Sragen adalah dimana BAZNAS Kabupaten Sragen ini pada tahun 2019 mendapat juara 1 BAZNAS Jateng Award 2019 Kategori pengelolaan Sistem Informasi BAZNAS (SIMBA) dan kategori operasional kelembagaan terbaik se Jawa Tengah (Sragenkab, 2019). Sehingga hal ini menarik dijadikan fenomena atau objek dalam penelitian ini.

Penelitian dengan tema serupa juga pernah dilakukan oleh Salmawati \& Fitri (2018) namun dengan studi kasus pada Baitul Maal Kota Banda Aceh. Adapun Penelitian oleh Amalia \& Widiastuti (2019) dengan studi kasus pada Lembaga Amil Zakat Surabaya. Kemudian Istiqomah \& Asrori (2019) studi kasus pada muzakki zakat mal di Rembang. Dan Penelitian oleh Putri (2019) serta Tho'in \& Marimin (2019) yang melakukan penelitian serupa namun studi kasus pada Lazis Jateng Cabang Solo. Maka berdasarkan perbedaan dari berbagai studi kasus dari Penelitian terdahulu tersebut. Maka dalam Penelitian ini walaupun mengangkat tema serupa yaitu mengenai minat muzakki dalam membayar zakat, namun kali ini peneliti meneliti studi kasus yang berbeda dan periode terbaru.

\section{Theory of Planned Behavior}

Theory of planned behavior merupakan pengembangan dari reason action theory yang dikemukaan oleh Fishbein dan Ajzen (1975). Reasoned action theory mempunyai bukti-bukti ilmiah bahwa niat untuk melaksanakan sesuatu perbuatan dikarenakan oleh dua alasan, yaitu norma subjektif dan sikap terhadap perilaku (Fishbein dan Ajzen, 1975). Beberapa tahun kemudian, Ajzen (1988) menambahkan satu faktor yaitu kontrol perilaku persepsian individu atau perceived behavioral control. Keberadaan faktor tersebut mengubah reasoned action theory menjadi Planned behavior theory.

Planned behavior theory mempunyai sebuah keyakinan terhadap perspektif kepercayaan yang mampu mempengaruhi seseorang untuk melaksanakan tingkah laku yang spesifik. Perspektif kepercayaan dilaksanakan melalui penggabungan beraneka ragam karakteristik, kualitas dan atribut atas informasi tertentu yang kemudian membentuk kehendak dalam bertingkah laku (Seni \& Ratnadi, 2017). Niat atau intensi merupakan keputusan dalam berperilaku melalui cara yang dikehendaki atau stimulus untuk melaksanakan perbuatan, baik secara sadar ataupun tidak (Corsini, 2002). Niat atau intensi inilah yang menjadikan awal terbentuknya perilaku seseorang. Teori planned behavior ini cocok digunakan guna mendeskripsikan perilaku apapun yang memerlukan perencanaan (Ajzen, 1991).

Menurut Wikamorys \& Rochmach (2017) menerangkan bahwa sikap terhadap perilaku, norma, dan persepsi pengendalian diri akan menimbulkan niat untuk melakukan sesuatu hal. Implikasi theory of planned behavior pada penelitian ini menguatkan variabel independen yaitu akuntabilitas, transparansi dan religiusitas sebagai bentuk faktor yang memengaruhi minat muzakki dalam membayar zakat. Akuntabilitas dan transparansi yang baik sebuah Lembaga Pengelola Zakat juga akan memengaruhi minat seseorang guna memilih Lembaga tersebut guna menunaikan zakatnya. 


\section{Minat}

Menurut Kamus Besar Bahasa Indonesia (KBBI), minat diartikan sebagai kecenderungan hati yang tinggi mengenai sesuatu hal (KBBI, 2005). Kemudian Slameto (2010) mengartikan minat sebagai suatu rasa keterikatan dan rasa suka terhadap sesuatu kegiatan dengan tidak adanya suruhan. Pada dasarnya, merupakan hal yang diterima dan korelasi personal. Kuat atau kedekatan relasi itu, maka besarnya daya tarik seseorang.

Minat diartikan sebagai sesuatu dalam diri seseorang yang terdiri atas harapan, perasaan, prinsi, yang tercampur dan ada pada satu wadah pemberian arah yang jelas pada personal, untuk keputusan ataupun pilihan (Triyawan, 2016). Pengertian minat lainnya menurut Yazid (2017) minat didefinisikan suatu kondisi atau keadaan orang memiliki daya tarik pada sesuatu dengan peminatan pendalaman ingin menggalinya, melakukan pembuktian pada suatu fokus.

Crow and Crow (dalam Saleh \& Wahab, 2004) mengklasifikasikan ada tiga faktor minat, antara lain:

a. Dorongan dari dalam diri individu, seperti kaingin tahuan, dorongan minum dan makan. Hal ini berarti adanya perasaan senang dan cenderung perhatian. Muzakki yang mengetahui akan hukum zakat adalah wajib bagi setiap muslim, mempunyai loyalitas pembayarannya.

b. Motif sosial, hal ini menumbuhkan minat seseorang untuk melakukan sesuatu hal. Dorongan faktor eksternal pada penentuan personal pembayarannya di Lembaga Pengelola Zakat, Misalnya dukungan dari orang terdekat ataupun yang ada disekelilingnya.

c. Faktor emosional, memiliki korelasi kaitannya pada perasaan, diperlihatkan dari rasa yakin pada kelembagaan untuk pengelolaannya.

\section{Zakat}

Zakat merupakan instrument hukum dan wakaf dimana merupakan instrument sukarela untuk mengabdi kepada orang miskin dan bagi orang yang membutuhkan untuk mencapai kesejahteraan sosial (Mikail, Ahmad, \& Adekunle, 2017). Menurut Fathoni (2015) zakat pembagiannya dua, fitrah dan maal, diperintahkan oleh nabi Muhammad SAW kepada umatnya pada tahun puasa Romadhon hingga hari akhir pada bulan Romadhon sebelum idhul fitri. Kedua zakat maal merupakan zakat mengenai kepemilikian harta benda tertentu yang sudah memenuhi syarat. Zakat maal meliputi zakat perak dan emas, zakat tumbuh-tumbuhan, zakat hasil panen, zakat perniagaan serta zakat profesi yang ada saat ini.

\section{Akuntabilitas}

Menurut Kamus Besar Bahasa Indonesia menerangkan bahwa akuntabilitas ialah perihal tanggungan atas kondisi yang bisa dimintakan tanggung jawab nya (KBBI, 2005). Menurut Mardiasmo (2002) Akuntabilitas dimaknai sebagai keharrusan yang memberi amanah menyajikan, melaporkan, pemberian tanggung jawab pengungkapan kegiatan yang ditanggungkan dengan mempunyai wewenang serta hak guna permintaan pertanggungjawabannya.

Konsep akuntabilitas oleh Kholmi (2012) memiliki tiga dimensi yaitu pertama relasi antar sesama, dengan lingkungan dan pencipta. Dalam Konteksnya, Allah sebagai yang memberikan amanah, yang memiliki kekuasaan, dan Manusia harus bertanggung jawab atas apa yang diperbuatnya pada Manusia, alam ataupun pada Tuhan.

\section{Transparansi}

Transparansi ialah penyajian pelaporan semua orang dengan transparan dan tidak ada yang ditutupi, berkaitan dengan pelaksaan dan pengelolaannya, dengan unsur yang menjadi dasar diambilnya keputusan dan dilaksanakannya aktivitas tersebut (Hasan, 2011). Menurut Abidin \& Rukmini (2011) keterbukaan mempunyai makna, kebijakan yang dilakukan dan dilaksanakan pada mekanisme atuapun caranya, regulasi yang ditetapkan lembaga denga jelas. Pada pengelolaan zakat, tujuannya menciptakan bahwasanya tidak ada yang ditutupi, keyakinan pada lembaga pengelolaan, meciptakan opini bahwasanya, mereka kompeten, jujur, dengan terciptanya rasa keyakinan tersebut, berbanding luru pada masyarakat yang bisa melihat atau melakukan akses mengetahui informasi yang jelas.

\section{Kerangka Pemikiran}

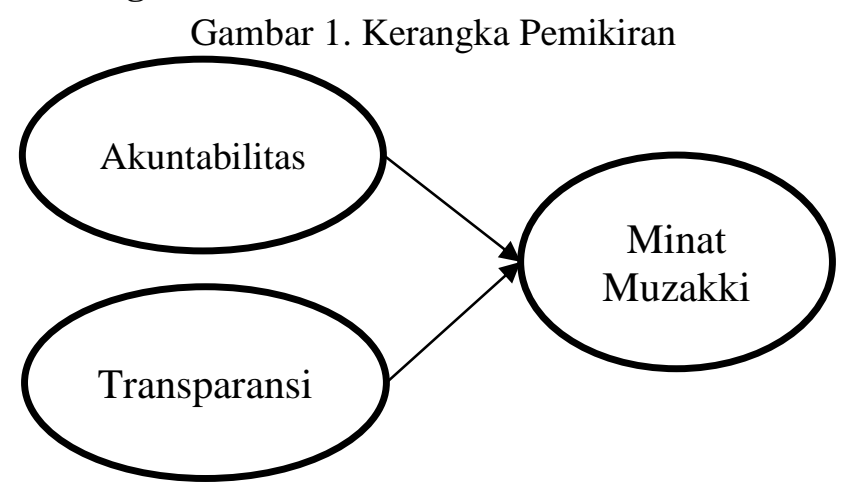




\section{Jurnal Ilmiah Ekonomi Islam, 7(01), 2021, 345}

\section{Pengembangan Hipotesis}

\section{Pengaruh Akuntabilitas Terhadap Minat \\ Muzakki Membayar Zakat}

Semakin tinggi akuntabilitas dari sebuah Lembaga maka akan meningkatkan minat seseorang. Akuntabilitas dapat mempengaruh minat sesorang untuk membayar zakat. Dalam pelaksanaan akuntabilitas, manajemen diminta memberikan informasi kepada publik. Informasi yang dibutuhkan yaitu berhubungan dengan akuntansi karena didalamnya terdapat laporan keuangan yang menjadi acuan dalam pelaksanaan. Hal ini akan berdampak terhadap minat seseorang untuk memilih laporan keungan yang baik dan juga sekaligus sejalan dengan teori minat yaitu dorongan dalam diri seseorang atas dasar rasa ingin tahu. Penelitian oleh Salmawati \& Fitri (2018) dan Amalia \& Widiastuti (2019) mengemukakan minat muzakki dipengaruhi signifikan oleh akuntabilitas.

H1: Akuntabilitas berpengaruh positif terhadap minat muzakki

\section{Pengaruh Transparansi Terhadap Minat Muzakki Membayar Zakat}

Semakin tinggi transparansi dari sebuah lembaga maka akan meningkatkan kepercayaan seseorang. Transparansi dari sebuah Lembaga Pengelola Zakat akan memengaruhi minat muzakki. Hal ini dikarenakan adanya dorongan dalam diri seseorang untuk memilih Lembaga yang transparan. Sehingga hal ini sejalan dengan teori minat yaitu motif sosial yang berarti membangkitkan untuk melakukan aktivitas tertentu. Hasil penelitian oleh Farhati (2019) mengemukakan transparasi berpengaruh terhadap minat muzakki.

H2 :Transparansi berpengaruh positif terhadap minat muzakki.

\section{METODE PENELITIAN}

Jenis penelitian ini merupakan penelitian deskriptif dengan pendekatan kuantitatif. Pra penelitian yang dilakukan oleh peneliti memperoleh informasi populasi dari BAZNAS Sragen sebanyak 8658 muzakki (BAZNAS, 2020). Teknik pengambilan sampel pada penelitian ini memakai teknik nonprobability sampling. Adapun teknik penentuan sampel pada penelitian ini menggunakan teknik insindental sampling. Dimana incidental sampling merupakan teknik pengambilan sampel dari populasi berdasarkan kebetulan, yakni siapa saja yang kebetulan dijumpai peneliti digunakan sebagai sampel, apabila cocok dengan sumber data. Rumus slovin digunakan dalam penelitian ini dikarenakan populasi dalam penelitian ini sudah diketahui. Kemudian untuk menentukan jumlah sampel digunakan rumus slovin dengan tingkat error sebesar $10 \%$ atau dengan kata lain tingkat kepercayaan atau kebenaran 90\%. Adapun rumus slovin sebagai berikut:

$$
n=\frac{N}{1+N e^{2}}
$$

Keterangan:

$\mathrm{n}=$ Jumlah responden atau ukuran sampel

$\mathrm{N}=$ Ukuran populasi

$\mathrm{e}=$ Prosentase tingkat error pengambilan sampel yang masih dapat ditolerir

Di dalam rumus slovin terdapat ketentuan:

Nilai $\mathrm{e}=0,05 \%$ untuk populasi dalam jumlah kecil Nilai e $=0,1 \%$ untuk populasi dalam jumlah banyak

Jadi rentang sampel pada slovin antara 5\%-10\% dari populasi. Dalam Penelitian ini jumlah sampel adalah 8658 tergolong banyak, maka digunakan tingkat error sebesar $0,1 \%$ atau $10 \%$. Sehingga didapat sampel sebagai berikut:

$$
\begin{aligned}
& n=\frac{8658}{1+\left(8.6580,10^{2}\right)} \\
& n=\frac{8658}{1+(86,58)} \\
& n=\frac{8658}{87,58}=100
\end{aligned}
$$

Berdasarkan hasil tersebut didapat jumlah sampel sebesar 100 muzakki. Teknik pengumpulan data pada penelitian ini menggunakan kuesioner. Teknik Analisa data pada penelitian ini menggunakan analisis regresi linear berganda.

\section{HASIL DAN PEMBAHASAN}

\subsection{Hasil penelitian}

Uji Validitas Variabel Akuntabilitas

Tabel 1. Uji Validitas Variabel Akuntabilitas

\begin{tabular}{|c|c|c|c|}
\hline Item & Rhitung & Rtabel & Keterangan \\
\hline X1.1 & 0,580 & 0,1966 & valid \\
\hline X1.2 & 0,741 & 0,1966 & valid \\
\hline X1.3 & 0,824 & 0,1966 & valid \\
\hline X1.4 & 0,759 & 0,1966 & valid \\
\hline X1.5 & 0,522 & 0,1966 & valid \\
\hline X1.6 & 0,704 & 0,1966 & valid \\
\hline
\end{tabular}

Sumber: Data diolah, 2021

Berdasarkan hasil diatas dapat diketahui jika semua item pertanyaan variabel akuntabilitas memiliki nilai rhitung > rtabel, maka dapat dikatakan semua item variabel akuntabilitas adalah valid. 
Uji Validitas Variabel Transparansi

Tabel 2. Uji Validitas Variabel transparansi

\begin{tabular}{|c|c|c|c|}
\hline Item & Rhitung & Rtabel & Keterangan \\
\hline X2.1 & 0,757 & 0,1966 & valid \\
\hline X2.2 & 0,877 & 0,1966 & valid \\
\hline X2.3 & 0,895 & 0,1966 & valid \\
\hline X2.4 & 0,759 & 0,1966 & valid \\
\hline X2.5 & 0,714 & 0,1966 & valid \\
\hline X2.6 & 0,361 & 0,1966 & valid \\
\hline X2.7 & 0,657 & 0,1966 & valid \\
\hline
\end{tabular}

Sumber: Data diolah, 2021

Berdasarkan hasil diatas dapat diketahui jika semua item pertanyaan variabel transparansi memiliki nilai rhitung > rtabel, maka dapat dikatakan semua item variabel transparansi adalah valid.

Uji Validitas Variabel Minat

Tabel 3. Uji Validitas Variabel Minat

\begin{tabular}{|c|c|c|c|}
\hline Item & Rhitung & Rtabel & Keterangan \\
\hline Y1.1 & 0,602 & 0,1966 & valid \\
\hline Y1.2 & 0,804 & 0,1966 & valid \\
\hline Y1.3 & 0,827 & 0,1966 & valid \\
\hline Y1.4 & 0,823 & 0,1966 & valid \\
\hline Y1.5 & 0,692 & 0,1966 & valid \\
\hline Y1.6 & 0,770 & 0,1966 & valid \\
\hline Y1.7 & 0,753 & 0,1966 & valid \\
\hline Y1.8 & 0,763 & 0,1966 & valid \\
\hline
\end{tabular}

Sumber: Data diolah, 2021

Berdasarkan hasil diatas dapat diketahui jika semua item pertanyaan variabel minat memiliki nilai rhitung > rtabel, maka dapat dikatakan semua item variabel minat adalah valid.

Uji Reliabilitas Variabel Akuntabilitas

Tabel 4. Uji Reliabilitas Variabel

\section{Akuntabilitas}

\begin{tabular}{rrr} 
Cronbach's Alpha & N of Items \\
\hline .766 & 7 \\
\hline
\end{tabular}

Sumber: Data diolah, 2021

Berdasarkan tabel diatas diperoleh nilai Cronsbach's Alpha sebesar 0,766 >0,70, maka dapat disimpulkan bahwa variabel akuntabilitas reliabel.

Uji Reliabilitas Variabel Transparansi

Tabel 5. Uji Reliabilitas Variabel

Transparansi

Reliability Statistics

Cronbach's Alpha

$\mathrm{N}$ of Items

.780 8

Sumber: Data diolah, 2021
Berdasarkan tabel diatas diperoleh nilai Cronsbach's Alpha sebesar 0,780 >0,70, maka dapat disimpulkan bahwa variabel akuntabilitas reliabel.

Uji Reliabilitas Variabel Minat

Tabel 6. Uji Reliabilitas Variabel Minat Reliability Statistics

\begin{tabular}{rrr}
\multicolumn{2}{c|}{ Cronbach's Alpha } & N of Items \\
\hline .781 & \\
\hline
\end{tabular}

Sumber: Data diolah, 2021

Berdasarkan tabel diatas diperoleh nilai Cronsbach's Alpha sebesar 0,781 >0,70, maka dapat disimpulkan bahwa variabel akuntabilitas reliabel.

Uji Koefisien Determinasi $\left(\mathbf{R}^{2}\right)$

Tabel 7. Uji $\mathbf{R}^{2}$

Model Summary

Adjusted Std. Error of

\begin{tabular}{ll|l} 
Model R R Square R Square the Estimate \\
\hline 1
\end{tabular}

\begin{tabular}{lllll}
\hline 1 & $.563^{\mathrm{a}}$ & .317 & .303 & 3.661 \\
\hline
\end{tabular}

a. Predictors: (Constant), $\mathrm{x} 2, \mathrm{x} 1$

Sumber: Data diolah, 2021

Berdasarkan hasil diatas diperoleh nilai Adjusted R Square sebesar 0,303 atau $30,3 \%$. Hal ini berarti bahwa variabel akuntabilitas dan transparansi dapat menjelaskan hubungan sebesar $30,3 \%$ terhadap variabel minat muzakki dalam membayar zakat, sedangkan sisanya yakni sebesar $69,7 \%$ dijelaskan oleh factor lain yang tidak diteliti pada penelitian ini. Uji t (parsial)

Tabel 8. Uji t

Coefficients $^{\mathrm{a}}$

Unstandardize Standardized

d Coefficients Coefficients $t \quad$ Sig. Std.

\begin{tabular}{|c|c|c|c|c|}
\hline Model & B & Error & Beta & \\
\hline 1 (Constant) & $\begin{array}{r}12.85 \\
9\end{array}$ & 3.708 & & 3.468 .001 \\
\hline $\mathrm{x} 1$ & .918 & .139 & .588 & 6.604 .000 \\
\hline $\mathrm{x} 2$ & -.095 & .087 & -.097 & -1.088 .279 \\
\hline
\end{tabular}

a. Dependent Variable: y1

Sumber: Data diolah, 2021

Berdasarkan tabel diatas diperoleh nilai sig pada variabel akuntabilitas yakni sebesar 0,000 , hal ini berarti bahwa H0 diterima dan Ha ditolak. Artinya bahwa terdapat pengaruh yang signifikan akuntabilitas terhadap minat muzakki membayar zakat. Kemudian untuk variabel transparansi diperoleh nilai sig sebesar 0,279 artinya HO ditolak 
dan Ha diterima, artinya tidak terdapat Pengaruh yang signfikan transparansi terhadap minat muzakki membayar zakat.

\section{Uji F (Simultan)}

\begin{tabular}{|lr|r|r|r|r|r}
\multicolumn{7}{c}{ Tabel 9. Uji F } \\
\multicolumn{7}{c}{ ANOVA } \\
Model & $\begin{array}{c}\text { Sum of } \\
\text { Squares }\end{array}$ & df & Mean & & \\
Square & F & Sig. \\
\hline 1 Regression & 603.843 & 2 & 301.922 & 22.529 & $.000^{b}$ \\
\hline Residual & 1299.947 & 97 & 13.402 & & \\
\hline Total & 1903.790 & 99 & & & \\
\hline
\end{tabular}

a. Dependent Variable: y1

b. Predictors: (Constant), $\mathrm{x} 2$, $\mathrm{x} 1$

Sumber: Data diolah, 2021

Berdasarkan hasil diatas dapat dilihat bahwa nilai sig diperoleh sebesar 0,000 , hal ini berarti bahwa secara simultan dalam hal ini akuntabilitas dan transparansi secara Bersama-sama berpengaruh terhadap minat muzakki membayar zakat.

\subsection{Pembahasan}

\section{Pengaruh Akuntabilitas Terhadap Minat Muzakki Membayar Zakat}

Berdasarkan hasil uji t diperoleh nilai koefisien sebesar 0,918 dan nilai sig sebesar 0,000 . Hal ini berarti bahwa akuntabilitas pada penelitian berpengaruh positif dan signifikan terhadap minat muzakki dalam membayar zakat di BAZNAS Kabupaten Sragen. Hal ini juga dapat diartikan ketika akuntabilitas BAZNAS Kabupaten sragen naik maka akan meningkatkan minat muzakki membayar zakat, namun sebaliknya jika akuntabilitas rendah maka minat muzakki juga rendah dalam hal membayar zakat di BAZNAS Sragen. Hasil ini mendukung penelitian oleh Salmawati \& Fitri ( 2018) dan Amalia \& Widiastuti (2019) yang juga mengemukakan bahwa minat muzakki dapat dipengaruhi oleh faktor akuntabilitas Lembaga Pengelola Zakat. Dalam hal ini hasil penelitian ini mendukung theory of planned behavior yakni dorongan untuk melakukan sesuatu hal dikarenakan adanya keinginan dalam diri Manusia. Masyarakat memiliki minat membayar zakat ketika sebuah Lembaga dalam hal ini BAZNAS Kabupaten Sragen memiliki akuntabilitas yang baik sehingga masyarakat tergerak untuk membayarkan zakatnya pada BAZNAS Kabupaten Sragen.

Pengaruh Transparansi Terhadap Minat Muzakki Membayar Zakat

Berdasarkan hasil uji t diperoleh nilai koefisien sebesar $-0,095$ dan nilai sig sebesar 0,279. Hal ini berarti bahwa transparansi pada penelitian berpengaruh negatif dan tidak signifikan terhadap minat muzakki dalam membayar zakat di BAZNAS Kabupaten Sragen. Hal ini juga dapat diartikan ketika transparansi BAZNAS Kabupaten sragen naik maka akan menurunkan minat muzakki membayar zakat, namun sebaliknya jika transparansi rendah maka minat muzakki akan naik dalam hal membayar zakat di BAZNAS Sragen. Hasil ini bertetangan dengan Farhati (2019) yang menyatakan bahwa transparasi berpengaruh signifikan pada minat muzakki. Namun hasil ini didukung penelitian oleh Wijayanti (2019). Hasil ini bertentangan dengan teori planned of behavior, hal ini berarti bahwa transparansi dari BAZNAS Kabupaten Sragen tidak mendorong masyarakat untuk mengeluarkat zakatnya dan lebih memilih untuk menyalurkan zakat secara langsung kepada kerabat, tetangga maupun saudara.

\section{KESIMPULAN}

Penelitian ini menyimpulkan bahwa secara simultan variabel akuntabilitas dan transparansi dari Lembaga BAZNAS Kabupaten Sragen berpengaruh pada minat muzakki dalam membayarkan zakatnya. Namun secara parsial akuntabilitas dapat memengaruhi secara signifikan pada minat muzakki, sedangkan transparansi tidak berpengaruh signifikan pada minat muzakki membayar zakat di BAZNAS Kabupaten Sragen. Saran untuk peneliti selanjutnya dapat menambah variabel baru sehingga menghasilkan hasil yang kompleks lagi. Untuk BAZNAS Kabupaten Sragen diharapkan untuk meningkatkan minat muzakki dengan membentuk badan amil pada tingkat desa-desa sehingga masyarakat di desa dapat menyalurkannya melalui Lembaga ambil yang sudah disediakan tersebut.

\section{UCAPAN TERIMA KASIH}

Alhamdulillah penulis ucapkan terimakasih kepada Allah SWT atas berkat dan karuniaNya sehingga penulis dapat menyelesaikan penelitian ini. Penulis juga mengucapkan terimakasih kepada semua pihak yang terlibat dalam penelitian ini yang tidak bisa disebutkan satu persatu. Kemudian penulis ucapkan juga kepada IAIN Salatiga sebagai institusi penulis dan BAZNAS Kabupaten Sragen sebagai objek dari penelitian ini. 


\section{Jurnal Ilmiah Ekonomi Islam, 7(01), 2021, 348}

\section{REFERENSI}

Abidin, H., \& Rukmini, M. (2011). Akuntabilitas dan Transparansi LSM: Problem dan Ikhtiar. Jakarta.

Ajzen, I. (1988). Attitudes, personality, and behavior. Milton Keynes: Open University Press dan Chicago, IL: Dorsey Press.

Ajzen, I. (1991). The theory of planned behavior. Organizational Behavior and Human Decision Processes 50.

Amalia, N., \& Widiastuti, T. (2019). Pengaruh Akuntabilitas, Transparansi, Dan Kualitas Pelayanan Terhadap Minat Muzaki Membayar Zakat (Studi Pada Laz Surabaya). Jurnal Ekonomi Syariah Teori Dan Terapan, 6(9), 1756-1769.

https://doi.org/10.1017/CBO9781107415324.00 4

Amelia, L., \& Murtani, A. (2020). Faktor-Faktor Yang Mempengaruhi Muzakki Dalam Membayar Zakat (Studi Baznas Sumatera Utara). Jurnal FEB, 1(1), 195-205.

Amymie, F. (2019). Optimalisasi Pendistribusian dan Pendayagunaan Dana Zakat dalam Pelaksanaan Tujuan Program Pembangunan Berkelanjutan (SDGs). Anida (Aktualisasi Nuansa Ilmu Dakwah), 17(1), 1-18. https://doi.org/10.15575/anida.v17i1.5046

Basri, Z. Z. (2015). Zakat Infak Sedekah dan Akuntansinya serta Potensinya dalam Meningkatkan Kesejahteraan Rakyat Miskin. Jakarta: Universitas Trisakti.

BPS. (2020). Badan Pusat Statistik. Retrieved January 24, 2021, from sp2010.bps.go.id

Corsini, R. (2002). The Dictionary of Psychology. London: Brunner/Rout Ledge.

Farhati, W. L. (2019). Pengaruh pengetahuan muzakki, akuntabilitas dan transparansi pengelolaan zakat terhadap minat membayar zakat pada organisasi pengelola zakat. Doctoral Dissertation, UIN Walisongo.

Fathoni, N. (2015). Fikih Zakat Indonesia. Semarang: CV Karya Abadi Jaya.

Harahap, K. R. (2019). Pengaruh Akuntabilitas Dan Transparansi Pengelolaan Zakat Terhadap Minat Muzakki (Studi Kasus: Baznas Provinsi Sumatera Utara). Universitas Islam Negeri Sumatera Utara.

Hasan, M. (2011). Manajemen Zakat (Cetakan I). Yogyakarta: Idea Press.
Hasrina, C. D., Yusri, Y., \& Sy, D. R. A. S. (2019). Pengaruh Akuntabilitas dan Transparansi Lembaga Zakat Terhadap Tingkat Kepercayaan Muzakki Dalam Membayar Zakat Di Baitul Mal Kota Banda Aceh. Jurnal Humaniora: Jurnal Ilmu Sosial, Ekonomi Dan Hukum, 2(1), 1-9. https://doi.org/10.30601/humaniora.v2i1.48

Ilyas Junjunan, M., Asegaf, M., \& Takwil, M. (2020). Pengaruh Transparansi, Akuntabilitas, dan IGCG terhadap Tingkat Kepercayaan Muzakki di Lembaga Amil Zakat Dompet Amanah Umat. Akuntansi: Jurnal Akuntansi Integratif, 6(2), 112-125. https://doi.org/10.29080/jai.v6i2.289

Istiqomah, D., \& Asrori. (2019). Pengaruh literasi terhadap kepercayaan muzaki pada lembaga pengelola zakat dengan akuntabilitas dan transparansi sebagai variabel intervening. Economic Education Analysis Journal, 8(1), 95109.

KBBI. (2005). Kamus Besar Bahasa Indonesia. Jakarta: Balai Pustaka.

Kholmi, M. (2012). Akuntabilitas dan Pembentukan Perilaku Amanah dalam Masyarakat Islam. Jurnal Studi Ekonomi Islam, 15(1). Retrieved from

http://ejournal.umm.ac.id/index.php/salam/articl e/view/1099

Lokadata.com. (2020). Lokadata.id.

Lubis, A. H. D. I. (2014). Analisis Faktor-Faktor Penyebab Keengganan Masyarakat Membayar Zakat Melalui Instansi Bazis/Laz Di Kota Medan ( Studi Kasus: Masyarakat Kecamatan Medan Tembung ). Jurnal Ekonomi Dan Keuangan, 3(4), 241-251. https://doi.org/10.1590/s180998232013000400007

Mardiasmo. (2002). Akuntansi Sektor Publik. Yogyakarta: Andi Yogyakarta.

Mikail, S. A., Ahmad, M. A. J., \& Adekunle, S. S. (2017). Utilisation of zakāh and waqf fund in micro-takāful models in Malaysia: an exploratory study. ISRA International Journal of Islamic Finance, $\quad 9(1)$, 100-105. https://doi.org/10.1108/IJIF-07-2017-010

Muthohar, A. M. (2016). Preferensi Masyarakat Terhadap Lembaga Zakat Dan Bentuk-Bentuk Pemberdayaan Dana Zakat. Inferensi, 10(2), 381. https://doi.org/10.18326/infs13.v10i2.381-404

Nurhasanah, S., \& Suryani. (2018). Maksimalisasi potensi zakat melalui peningkatan kesadaran masyarakat siti nurhasanah. JEBI (Jurnal Ekonomi Dan Bisnis Islam), 3(2), 185-194. 
PIRAC. (2007). Mensejahterakan Umat dengan Zakat. Retrieved from Public Interest Research And Advocacy Centre website: www.pirac.org/2012/05/25/mensejahterakanumat-dengan-zakat/

Putri, S. A. R., \& Tho'in, M. (2019, October). Effect of income rate, education, religiosity to muzakki interest to pay zakat; Case study of National Amil Zakat Board Central Java. In 2018 International Conference on Islamic Economics and Business (ICONIES 2018) (pp. 406-409). Atlantis Press.

Rahman, T. (2015). AKUNTANSI ZAKAT , INFAK DAN SEDEKAH ( PSAK 109 ): Upaya Peningkatan Transparansi dan Akuntabilitas Organisasi Pengelola Zakat ( OPZ ). Muqtasid, 6(109), 141-164.

Saleh, A. R., \& Wahab, M. A. (2004). Psikologi Suatu Pengantar (dalam Perspektif Islam) (Cetakan I). Jakarta: Prenada Media.

Salmawati, \& Fitri, M. (2018). Pengaruh tingkat pendapatan, religiusitas, akuntabilitas dan kualitas pelayanan terhadap minat muzakki membayar zakat di baitul mal kota banda aceh. Jimeka, 3(1), 54-66.

Seni, N. N. A., \& Ratnadi, N. M. D. (2017). Theory of Planned Behavior Untuk Memprediksi Niat Berinvestasi. E-Jurnal Ekonomi Dan Bisnis Universitas Udayana, 12, 4043. https://doi.org/10.24843/eeb.2017.v06.i12.p01

Slameto. (2010). Belajar dan Faktor-Faktor yang Mempengaruhinya. Jakarta: Rineka Cipta.

Sragenkab. (2019). BAZNAS Sragen Raih Juara 1 BAZNAS Jateng Award 2019. Retrieved from sragenkab.go.id/berita-1782.html

Sumadi, S. (2017). Optimalisasi Potensi Dana Zakat, Infaq, Sadaqah Dalam Pemerataan Ekonomi Di Kabupaten Sukoharjo (Studi Kasus di Badan Amil Zakat Daerah Kab. Sukoharjo). Jurnal Ilmiah Ekonomi Islam, 3(01), 16-26.
Tho'in, M., \& Marimin, A. (2019). Pengaruh Tingkat Pendapatan, Tingkat Pendidikan, dan Tingkat Religiusitas Terhadap Minat Muzakki Membayar Zakat. Jurnal Ilmiah Ekonomi Islam, 5(3), 225. https://doi.org/10.29040/jiei.v5i3.678

Triyawan, A. (2016). Analisis faktor-faktor yang mepengaruhi muzakki membayar zakat di BAZNAS Yogyakarta. Islamic Economics Journal, 2(1). https://doi.org/10.21111/iej.v2i1.970

Widiyanto. (2017). An exploratory study on understanding and awareness of paying zakat. Proceedings 5th Asean's International Conference on Islamic Finance, 1 st $\mathrm{Ed}$, (UNISSA Press), 467-482.

Wijayanti, Di. (2019). Pengaruh Religiusitas, Transparansi Dan Kualitas Membayar, Pelayanan Terhadap Minat Muzakki Dalam DIY, Zakat di LAZ Dan BAZ. Universitas Ahmad Dahlan.

Wikamorys, D. A., \& Rochmach, T. N. (2017). Aplikasi Theory Of Planned Behavior Dalam Membangun Niat Pasien Untuk Melakukan Operasi Katarak. Jurnal Adminitrasi Kesehatan Indonesiarasi Kesehatan Indonesia, 5, 32-40.

Yazid. (2017). Faktor-Faktor Yang Mempengaruhi Minat Muzakki Dalam Menunaikan Zakat Di Nurul Hayat Cabang Jember. Economic: Jurnal Ekonomi Dan Hukum Islam, 8(2), 173-198.

Yuliafitri, I., \& Khoiriyah, A. N. (2016). Pengaruh Kepuasan Muzakki, Transparansi dan Akuntabilitas Pada Lembaga Amil Zakat terhadap Loyalitas Muzakki (Studi Persepsi pada LAZ Rumah Zakat). Islamicocomic: Jurnal Ekonomi Islam, 7(2), 205-218. 